\title{
Effect of Saccharomyces cerevisiae fermentation product on ruminal fermentation and nutrient utilization in dairy cows
}

\author{
A. N. Hristov, ${ }^{* 1}$ G. Varga, ${ }^{*}$ T. Cassidy, ${ }^{*}$ M. Long, ${ }^{*}$ K. Heyler, ${ }^{*}$ S. K. R. Karnati,† B. Corl, $\ddagger$ C. J. Hovde, $\S$ \\ and I. Yoon\# \\ *Department of Dairy and Animal Science, Pennsylvania State University, University Park 16802 \\ †Department of Animal Sciences, The Ohio State University, Columbus 43210 \\ ‡Department of Dairy Science, Virginia Polytechnic Institute and State University, Blacksburg 24061 \\ $\S$ Department of Microbiology, Molecular Biology and Biochemistry, University of Idaho, Moscow 83844 \\ \#Diamond V Mills, Cedar Rapids, IA 52405
}

\section{ABSTRACT}

The goal of this experiment was to investigate the effect of yeast culture (Saccharomyces cerevisiae) on rumen fermentation, nutrient utilization, and ammonia and methane emission from manure in dairy cows. Eight ruminally cannulated Holstein cows were allocated to 2 dietary treatments in a crossover design. Treatments were control (no yeast culture) and XP (yeast culture, fed at $56 \mathrm{~g} /$ head per day; XP, Diamond V Mills Inc., Cedar Rapids, IA). Dry matter intake, milk yield, milk composition, and body weight were similar between treatments. Milk urea nitrogen concentration was also not affected by treatment. Rumen $\mathrm{pH}$ was similar between the control and XP treatments, but rumen ammonia concentration tended to be lower with XP than with the control. Treatment had no effect on concentrations of total or individual volatile fatty acids, protozoal counts, polysaccharide-degrading activities (except amylase activity that tended to be increased by XP), or methane production in the rumen. Urinary $\mathrm{N}$ losses did not differ significantly between treatments, but allantoin and total purine derivative excretions and the estimated microbial $\mathrm{N}$ outflow from the $\mathrm{ru}-$ men tended to be increased by XP compared with the control treatment. Total-tract apparent digestibility of dietary nutrients was not affected by XP. Milk fatty acid composition was also not altered by XP supplementation. Cumulative (253 h) ammonia and methane emissions from manure, measured in a steady-state gas emission system, were slightly decreased by XP. Overall, the yeast culture tested had little effect on ruminal fermentation, digestibility, or $\mathrm{N}$ losses, but tended to reduce rumen ammonia concentration and increase microbial protein synthesis in the rumen, and decreased ammonia and methane emissions from manure.

Received May 13, 2009.

Accepted October 23, 2009

${ }^{1}$ Corresponding author: anh13@psu.edu
Key words: yeast culture, rumen fermentation, nitrogen losses, manure emissions

\section{INTRODUCTION}

Yeast products (YP) based on Saccharomyces cerevisiae strains have been used with variable success to favorably modify the ruminal environment and promote microbial growth in ruminants. Recent metaanalyses have reported improvements in cow performance (Desnoyers et al., 2009; Robinson and Erasmus, 2009), but the mechanisms of the effect of YP are not completely understood. Provision of soluble growth factors (amino acids, organic acids such as malic acid, B vitamins) and oxygen scavenging may be involved (Newbold et al., 1996; Callaway and Martin, 1997). A recent report suggested stabilization of ruminal $\mathrm{pH}$ through decreased lactate production (Marden et al., 2008) by live yeast. Being aerobic organisms, however, yeast are unlikely to proliferate in the rumen and yet negligible amounts of yeast (live or not) are reportedly beneficial to the ruminal microbial population (Beauchemin et al., 2006). As a result, increased total viable and cellulolytic bacteria counts (Harrison et al., 1988; Newbold et al., 1995) and microbial protein synthesis and outflow from the rumen have been reported in some studies (Erasmus et al., 1992), but not in others (Firkins et al., 1990). In one study, yeast culture (YC; Trichosporon sericeum) decreased methane production in the rumen of sheep (Mwenya et al., 2004).

Rumen fibrolytic bacteria have a high preference for ammonia (Bryant, 1973) as their N source. Therefore, if the growth of fiber-degrading bacteria in the rumen is enhanced by YP supplementation, an increase in overall utilization of ruminal ammonia for microbial protein synthesis should be expected. In some studies such effects have been observed (Enjalbert et al., 1999, S. cerevisiae YC), but in others YP had no effect (Newbold et al., 1996; Mwenya et al., 2004; Longuski et al., 2009, S. cerevisiae or T. sericeum, live yeast or YC) or 
even resulted in increased ruminal ammonia concentration (Newbold et al., 1998, YC). If ruminal microbial growth, specifically that of the fibrolytic bacteria, is enhanced by YP supplementation and this results in a more efficient conversion of ruminal ammonia into microbial protein, the overall utilization of dietary $\mathrm{N}$ in the ruminant animal may be improved. Such improvement may result in decreased urinary $\mathrm{N}$ losses. Because urinary urea is the primary source of ammonia emitted from cattle manure (Bussink and Oenema, 1998), a reduction in urinary urea excretion may mitigate ammonia emissions from manure. To our knowledge, the effect of YP on ammonia losses from cattle manure has not been studied.

Therefore, the objective of this experiment was to investigate the effect of an $S$. cerevisiae fermentation product on ruminal fermentation, urinary $\mathrm{N}$ losses, and the ammonia-emitting potential of manure in highproducing dairy cow. Our hypothesis was that the $S$. cerevisiae fermentation product would reduce ammonia concentration in the rumen and urinary $\mathrm{N}$ excretion, which would result in reduced manure ammonia emissions.

\section{MATERIALS AND METHODS}

Animals involved in this study were cared for according to the guidelines of the Pennsylvania State University Animal Care and Use Committee. The committee reviewed and approved the experiment and all procedures carried out in the study.

\section{Animals and Experimental Design}

Eight multiparous Holstein cows $(639 \pm 16.4 \mathrm{~kg}$ of BW; $91 \pm 4.5$ DIM at the beginning of the trial) fitted with 10-cm ruminal cannulas (Bar Diamond, Parma, ID) were used in this experiment. Cows were subjected to the experimental treatments in a 2-period, crossover design trial. Treatments were control (no $\mathrm{YC}$ ) and $S$. cerevisiae fermentation product, fed at 56 $\mathrm{g} /$ head per day (XP). The $S$. cerevisiae fermentation product (Original XP), a fully fermented YC containing metabolites of yeast fermentation produced under a controlled production process was from Diamond $\mathrm{V}$ Mills Inc. (Cedar Rapids, IA). The basal diet fed in this experiment (as TMR; Table 1) was formulated (NRC, 2001) to meet the nutrient requirements (at $27.5 \mathrm{~kg} / \mathrm{d}$ of DMI) of a Holstein cow yielding $47 \mathrm{~kg}$ of milk/d with $3.70 \%$ milk fat and $3.05 \%$ milk true protein. The TMR was mixed by using a Kuhn Knight Model 3142 Reel Auggie Mixer Wagon (Broadhead, WI) and fed at 0800 and $2000 \mathrm{~h}$ (half of the daily allowed feed at each feeding). The XP was top-dressed with the morning
Table 1. Ingredient and chemical composition of the basal diet fed in the trial

\begin{tabular}{|c|c|}
\hline Item & Amount \\
\hline \multicolumn{2}{|l|}{ Ingredient, $\%$ of DM } \\
\hline Corn silage $^{1}$ & 34.8 \\
\hline Corn grain, ground & 11.2 \\
\hline Alfalfa haylage $^{2}$ & 9.8 \\
\hline Grass hay ${ }^{3}$ & 5.9 \\
\hline Canola meal, mechanically extracted & 9.0 \\
\hline Soybean seeds, whole, heated & 7.4 \\
\hline Cookie byproduct ${ }^{4}$ & 6.0 \\
\hline Turbo meal ${ }^{5}$ & 3.6 \\
\hline Cottonseed hulls & 4.5 \\
\hline Sugar blend ${ }^{6}$ & 4.3 \\
\hline Mineral/vitamin premix $^{7}$ & 3.5 \\
\hline \multicolumn{2}{|l|}{ Composition, ${ }^{8} \%$ of DM } \\
\hline $\mathrm{CP}$ & 15.9 \\
\hline Soluble protein & 5.7 \\
\hline $\mathrm{RDP}^{9} \mathrm{P}$ & 9.6 \\
\hline NDF & 31.0 \\
\hline $\mathrm{ADF}$ & 20.4 \\
\hline $\mathrm{NE}_{\mathrm{J}}, \mathrm{Mcal} / \mathrm{kg}$ & 1.67 \\
\hline $\mathrm{NFC}^{9}$ & 45.2 \\
\hline $\mathrm{Ca}$ & 0.96 \\
\hline $\mathrm{P}$ & 0.39 \\
\hline
\end{tabular}

${ }^{1}$ Corn silage was 34\% DM and (\% of DM) 39\% NDF, $9 \% \mathrm{CP}$, and $39 \%$ starch.

${ }^{2}$ Alfalfa haylage was $43 \%$ DM and (\% of DM) $41 \%$ NDF and $18 \%$ CP.

${ }^{3}$ Grass hay contained (\% of DM) $70 \%$ NDF and $8 \%$ CP.

${ }^{4}$ Cookie byproduct (Bakery Feeds, Honey Brook, PA) contained (\% of DM) $9 \% \mathrm{CP}, 8 \%$ ether extract, and $5 \%$ crude fiber.

${ }^{5}$ Turbo meal is heat-treated soybean meal (J. L. Moyer \& Sons Inc., Turbotville, PA) and contained (\% of DM) $44 \%$ CP, $4 \%$ soluble CP, and $24 \%$ RUP.

${ }^{6}$ Sugar blend (Westway Feed Products, Tomball, TX) contained (\% of DM) $3.9 \% \mathrm{CP}$ and $66 \%$ total sugar.

${ }^{7}$ The premix contained (\%, as-is basis) trace mineral mix, 0.88; $\mathrm{MgO}$ $(54 \% \mathrm{Mg}), 8.3 ; \mathrm{NaCl}, 6.4$; vitamin ADE premix, 1.73; limestone, 35.8; selenium premix, 1.09; and dry corn distillers grains with solubles, 45.8. Composition: Ca, $14.1 \%$; P, 0.35\%; Mg, $4.58 \%, \mathrm{~K}, 0.41 \%$; S, $0.31 \%$; $\mathrm{Mn}, 1,071 \mathrm{mg} / \mathrm{kg}$; Cu, $358 \mathrm{mg} / \mathrm{kg}$; Zn, 1,085 mg/kg; Fe, $181 \mathrm{mg} / \mathrm{kg}$; $\mathrm{Se}, 6.67 \mathrm{mg} / \mathrm{kg}$; Co, $5.4 \mathrm{mg} / \mathrm{kg}$; I, $13.4 \mathrm{mg} / \mathrm{kg}$; vitamin A, 262,101 IU/ $\mathrm{kg}$; vitamin D, 65,421 IU/kg; and vitamin E, 1,971 IU/kg.

${ }^{8}$ As analyzed by Cumberland Valley Analytical Services (Maugansville, MD).

${ }^{9}$ Estimated based on NRC (2001).

feed. Feeding was ad libitum to about $5 \%$ orts. Each experimental period consisted of $21 \mathrm{~d}$ for adaptation to the diet and $7 \mathrm{~d}$ for sampling. Cows were housed in a tiestall facility during the trial and were exercised for 1.5-h periods before each milking. Cows had free access to fresh water and received recombinant bovine somatotropin every $14 \mathrm{~d}$ starting at 63 DIM.

\section{Measurements}

Individual forage, TMR, and refusals samples were collected every other day and concentrate feeds were sampled weekly. Samples were composited and the composite samples were analyzed for $\mathrm{DM}\left(65^{\circ} \mathrm{C}\right.$ in a 
forced-air oven, dried to a constant weight) and ash/ organic matter (AOAC, 2000), N (Kjeldahl method; AOAC, 1980), NDF (Van Soest et al., 1991), and starch (starch assay kit, Megazyme International Ireland Ltd., Wicklow, Ireland; McCleary et al., 1994). A heat-stable $\alpha$-amylase and sodium sulfite were used in the NDF analysis, and NDF was expressed inclusive of residual ash. Composite TMR samples were also analyzed for acid-insoluble ash (AIA; Van Keulen and Young, 1977).

Whole ruminal content samples were collected at 0 , $2,4,6,8,10,14,18,24,30$, and $36 \mathrm{~h}$ following the morning feeding on d 23 and 24 of each period. $\mathrm{Ru}-$ minal samples were collected from 4 locations in the rumen and the reticulum (approximately $250 \mathrm{~g}$ each) and composited. Aliquots were filtered through 2 layers of cheesecloth, immediately analyzed for $\mathrm{pH}$, and processed for analyses of ammonia (Chaney and Marbach, 1962) and VFA (Yang and Varga, 1989), total free amino acids (TFAA, ninhydrin procedure; Snell and Snell, 1954), protozoal counts and genera distribution, and polysaccharide-degrading (carboxymethyl cellulase, xylanase, and amylase) activities (Hristov et al., 1998). Samples for protozoa were counted according to Dehority (1993). Generic distribution of protozoa was determined from the total number of cells of each genera counted in 100 fields using the Sedgewick-Rafter chamber (Hausser Scientific, Horsham, PA).

Methane production in the rumen was measured utilizing the sulfur hexafluoride $\left(\mathrm{SF}_{6}\right)$ tracer technique (Johnson et al., 1994). The $\mathrm{SF}_{6}$ permeation tubes were prepared by K. Johnson (Washington State University, Pullman, WA). The tubes were placed in the reticulum of the cows on $\mathrm{d} 1$ of the experiment and remained there throughout the study. Gas samples for methane analysis were collected directly from the rumen through modified rumen cannula lids (for description, see Hristov et al., 2009). The modified cannula lids were replaced $1 \mathrm{~h}$ before collection of the first gas sample, which took place on d 28 of each experimental period. Using a syringe, two 180-mL gas samples were collected through a valve fitted to the cannula lid into sealed and vacuumed $200-\mathrm{mL}$ serum bottles. Sampling started $2 \mathrm{~h}$ after the a.m. feeding, and gas samples were collected every hour for $6 \mathrm{~h}$; that is, at 2,3,4,5, and $6 \mathrm{~h}$ after the a.m. feeding. Gas samples were analyzed for methane and $\mathrm{SF}_{6}$ on a photoacoustic gas analyzer (Innova model 1412; AirTech Instruments, Ballerup, Denmark). Production of methane was calculated as the release rate of $\mathrm{SF}_{6}$ times the ratio of the concentration of methane to $\mathrm{SF}_{6}$ in the ruminal headspace (Johnson et al., 1994).

The effect of XP on ruminal methanogen populations was analyzed using denaturing gradient gel electrophoresis (DGGE) analysis on composited rumen samples collected at different time points during the feeding cycle. Details of the procedure are described elsewhere (Hristov et al., 2009).

Fecal samples (400 g per sampling) were collected from the rectum or the ground, when fresh, at the beginning of each sampling period: at 0900, 1500, and $2100 \mathrm{~h} \mathrm{(d} \mathrm{21),} \mathrm{and} \mathrm{at} \mathrm{0300,} \mathrm{0600,} \mathrm{1200,} 1800$ (d 22), and $0000 \mathrm{~h}$ (d 23). Samples were composited per animal and period on an as-is basis, dried at $65^{\circ} \mathrm{C}$ in a forced-air oven to constant weight, and ground through a $1-\mathrm{mm}$ sieve. Samples were analyzed for OM, N, NDF, starch, and AIA (as indicated above). Apparent total-tract digestibility was estimated using AIA as an intrinsic digestibility marker (Foley et al., 2006). At each sampling, a second fecal sample (approximately $300 \mathrm{~g}$ ) was collected, composited (per cow and period), and frozen immediately $\left(-20^{\circ} \mathrm{C}\right)$ for analysis of gaseous emissions from manure (ammonia, methane, and carbon dioxide).

Total urine was collected on d 25, 26, 27, and 28 of each period. Urinary catheters (22 French, $75 \mathrm{~mL}, \mathrm{C}$. R. Bard Inc., Covington, GA) were positioned in the cows $24 \mathrm{~h}$ before initiation of the urine collection. Urine samples were acidified during collection to a $\mathrm{pH}<3.0$ by addition of $2 \mathrm{M}$ sulfuric acid. Aliquots were diluted 1:10 with distilled water, stored frozen at $-20^{\circ} \mathrm{C}$, and later analyzed for N, allantoin (Chen, 1989), and uric acid (uric acid kit 1051, Stanbio Laboratory, San Antonio, TX). Urinary purine derivative (PD; allantoin and uric acid) excretion was used to estimate duodenal microbial N (MN) flow. The duodenal flow of microbial purine bases (MPB) was estimated using the improved equation proposed by Firkins et al. (2006): duodenal MPB flow $(\mathrm{mmol} / \mathrm{d})=17.0+1.037 \times$ urinary allantoin excretion $(\mathrm{mmol} / \mathrm{d})$. Microbial $\mathrm{N}$ flow at the duodenum was calculated as duodenal $\mathrm{MN}$ flow ( $\mathrm{g}$ of $\mathrm{N} / \mathrm{d})=$ duodenal MPB flow $(\mathrm{mmol} / \mathrm{d}) \times 70 \div(0.134 \times$ $1,000)$, where 70 is the $\mathrm{N}$ content of purines $(\mathrm{mg}$ of $\mathrm{N} /$ mmol; Chen and Gomes, 1992) and 0.134 is the ratio of purine $\mathrm{N}$ to total $\mathrm{N}$ in rumen microorganisms assumed from Valadares et al. (1999; lactating Holstein cows fed various ratios of alfalfa forage to high-moisture corn grain-based concentrate). Duodenal MN flow was also estimated based on Chen and Gomes (1992) as follows: 1) absorption of MPB $(\mathrm{mmol} / \mathrm{d})=(\mathrm{PD}-0.385 \times$ $\left.\mathrm{BW}^{0.75}\right) \div 0.85$, where $\mathrm{PD}$ is the urinary $\mathrm{PD}$ excretion (allantoin and uric acid; $\mathrm{mmol} / \mathrm{d}$ ), $0.385 \mathrm{mmol} / \mathrm{kg}$ of $\mathrm{BW}^{0.75}$ is a correction for endogenous $\mathrm{PD}$, and 0.85 is a recovery coefficient; and 2) duodenal MN flow ( $\mathrm{g}$ of $\mathrm{N} / \mathrm{d})=($ absorbed MPB $\times 70) \div(0.83 \times 0.134 \times$ $1,000)$, where 70 and 0.134 are coefficients as described above and 0.83 is digestibility of microbial purines.

At the beginning of each urine collection period, an unacidified urine sample (approximately $2 \mathrm{~L}$ ) was col- 
lected from each cow and frozen immediately $\left(-20^{\circ} \mathrm{C}\right)$ for analysis of gaseous emissions from manure.

Ammonia, methane, and carbon dioxide emitting potential of manure was measured in a steady-state gas emission system (Wheeler et al., 2007). Briefly, the system consists of 3.8-L capacity glass jars (incubation chambers) placed in a controlled temperature water bath, sweep air flow regulators, a multiplexer relay board, and a gas analyzer. Emission measurements in this experiment were conducted at $25^{\circ} \mathrm{C}$ with $2 \mathrm{~L} / \mathrm{min}$ sweep air flow. Feces and urine were thawed and mixed 1.7:1 (252 $\mathrm{g}$ of feces and $148 \mathrm{~g}$ of urine per jar) and incubated for $235 \mathrm{~h}$. The feces:urine ratio was chosen based on experiments from the laboratory of the senior author (A. N. Hristov), in which fecal and urinary N outputs were measured in lactating dairy cows. Ammonia, methane, and carbon dioxide concentrations in the gas leaving the chambers were measured by using the Innova gas analyzer. Gas measurements were taken every $30 \mathrm{~min}$.

On d 27 and 28 of each sampling period, blood samples were collected from the tail vein/artery before $(0$ h) and $6 \mathrm{~h}$ after the a.m. feeding. Plasma was collected after centrifugation at $1,500 \times g$ for $40 \mathrm{~min}$, frozen at $-40^{\circ} \mathrm{C}$, and later analyzed for urea N (kit 0580, Stanbio Laboratory) and glucose (kit 1075, Stanbio Laboratory).

Milk yield data were collected daily, and milk samples (a.m. and p.m. milkings) for composition analyses (Dairy One, Ithaca, NY) were collected on $3 \mathrm{~d}$ during the last 2 wk of each period.

Milk samples for fatty acid composition were collected and stored at $-20^{\circ} \mathrm{C}$ until analysis. Milk samples were extracted using the method of Hara and Radin (1978) and methylated using the procedure of Christie (1982) as described by Kelsey et al. (2003). Fatty acid methyl esters were analyzed by gas chromatography (Hewlett Packard GC system $6890 \mathrm{~N}$ with flame ionization detector; Agilent Technologies Inc., Santa Clara, CA) using a CP-Sil 88 capillary column $(100 \mathrm{~m} \times 0.25 \mathrm{~mm}$ i.d. with $0.20-\mu \mathrm{m}$ film thickness, Varian Inc., Palo Alto, $\mathrm{CA})$. Analysis involved a programmed temperature run. The oven temperature was initially $80^{\circ} \mathrm{C}$ and was increased by $2^{\circ} \mathrm{C} / \mathrm{min}$ until $190^{\circ} \mathrm{C}$ where it remained for 15 min. Injector and detector temperatures were $250^{\circ} \mathrm{C}$. Hydrogen flow through the column was maintained at $1 \mathrm{~mL} / \mathrm{min}$ and the split ratio at injection was 100:1. Gas flows to the flame-ionization detector were $25 \mathrm{~mL} /$ min for hydrogen, $400 \mathrm{~mL} / \mathrm{min}$ for air, and $40 \mathrm{~mL} /$ min for the nitrogen make-up gas. Fatty acid methyl esters were identified using pure methyl ester standards (NuChek Prep, Elysian, MN). A characterized butter reference standard (CRM 164; Commission of European Communities, Community Bureau of Reference,
Brussels, Belgium) was used as an external standard to correct for losses of short-chain fatty acids during sample preparation.

\section{Statistical Analysis}

Data were analyzed using PROC MIXED (2003; SAS Inst. Inc., Cary, NC). Intake, digestibility, some rumen fermentation data, urinary excretion, milk composition data, and end-point (235 h) gas (ammonia, methane, and carbon dioxide) emissions from manure were analyzed assuming a crossover design. The 3 milk composition samples collected during each experimental period were averaged per cow, and the average values were used in the statistical analysis and to calculate FCM, ECM, and milk fat and protein yields. The model used was

$$
\mathrm{Y}_{\mathrm{ijkl}}=\mu+\mathrm{G}_{\mathrm{i}}+\mathrm{C}(\mathrm{G})_{\mathrm{ij}}+\mathrm{P}_{\mathrm{k}}+\tau_{\mathrm{l}}+\mathrm{e}_{\mathrm{ijk} \mathrm{l}},
$$

where $\mu$ is the overall mean, $G_{i}$ is the group, $C(G)_{i j}$ is the cow within group, $\mathrm{P}_{\mathrm{k}}$ is the kth period, $\tau_{1}$ is the lth treatment, with the error term $\mathrm{e}_{\mathrm{ijkl}}$ assumed to be normally distributed with mean $=0$ and constant variance. Group and cow within group were random effects and all others were fixed.

Ruminal pH, ammonia and VFA concentrations, ruminal methane production rate, DMI, and milk yield data were analyzed as repeated measures assuming a crossover design and an ar(1) covariance structure. The model used was

$$
\begin{aligned}
Y_{i j k l m}=\mu+ & G_{i}+C(G)_{i j}+P_{k}+\tau_{l}+D_{m} \\
& +\tau D_{l m}+e_{i j k l m},
\end{aligned}
$$

where $\mu$ is the overall mean, $G_{i}$ is the group, $C(G)_{i j}$ is the cow within group, $\mathrm{P}_{\mathrm{k}}$ is the kth period, $\tau_{\mathrm{l}}$ is the lth treatment, $D_{m}$ is the time effect, $\tau D_{l m}$ is the treatment $\times$ time interaction with the error term $\mathrm{e}_{\mathrm{ijk} \mathrm{klm}}$ assumed to be normally distributed with mean $=0$ and constant variance. Group and cow within group were random effects and all others were fixed.

Cumulative gaseous (ammonia and methane only) emissions from manure data were fitted (PROC NLIN, SAS) to a single rectangular 2-parameter hyperbola model of the type: $\mathrm{f}=a \times \mathrm{x} \div(b+\mathrm{x})$, in which $a$ represented the theoretical maximum of ammonia or methane emissions. The average proportion of the variance explained by the models (regression sum of squares $\div$ uncorrected total sum of squares) was 0.92 \pm 0.022. Estimated maximum emission and overall emission lines were compared between treatments us- 
ing the dummy variable regression technique (PROC NLMIXED, SAS; Bates and Watts, 1988).

Statistical differences were declared at $P \leq 0.05$. Differences between treatments at $0.05 \leq P \leq 0.10$ were considered as a trend toward significance.

\section{RESULTS}

The XP treatment had no effect on rumen $\mathrm{pH}$ during the sampling cycle (Table 2). Ammonia concentration tended to be decreased $(P=0.08)$ by XP compared with the control. The XP had no effect on concentration of TFAA, total and individual VFA, or acetate to propionate ratio, except for valerate concentration, which was increased $(P=0.05)$. No treatment by time interaction was observed for $\mathrm{pH}$, ammonia and TFAA concentrations, or total and individual VFA. Total protozoal and individual genera counts were not different between the control and XP. Entodinium spp. represented approximately $94 \%$ of the total protozoa in this experiment. Carboxymethylcellulase and xylanase activities of ruminal contents were also not affected by treatment, but amylase activity tended to be increased $(P=0.10)$ by XP compared with the control.

Methane production rate in the rumen within the $6 \mathrm{~h}$ of sampling was similar between the control and

Table 2. Effect of yeast culture (XP, Diamond V Mills, Cedar Rapids, IA) on rumen fermentation and blood metabolites in dairy cows $[\mathrm{n}=176$, rumen $\mathrm{pH}$, ammonia, and VFA data; $\mathrm{n}=80$, methane production data; $\mathrm{n}=16$, total free AA, polysaccharide-degrading (PSD) activities, protozoal counts, blood metabolites, and urinary purine derivative $(\mathrm{PD})$ data]

\begin{tabular}{|c|c|c|c|c|}
\hline Item & Control & $\mathrm{XP}$ & SEM & $P$-value \\
\hline \multicolumn{5}{|l|}{ Rumen } \\
\hline $\mathrm{pH}$ & 6.03 & 5.96 & 0.056 & $0.18^{1}$ \\
\hline Ammonia, $\mathrm{m} M$ & 3.6 & 3.0 & 0.28 & $0.08^{2}$ \\
\hline $\mathrm{TFAA},{ }^{3} \mathrm{~m} M$ & 3.3 & 2.5 & 0.36 & 0.16 \\
\hline Total VFA, mM & 119.0 & 119.3 & 2.46 & $0.91^{4}$ \\
\hline Acetate & 69.2 & 68.4 & 0.83 & 0.54 \\
\hline Propionate & 27.8 & 29.5 & 1.68 & 0.23 \\
\hline Isobutyrate & 1.34 & 1.29 & 0.022 & 0.15 \\
\hline Butyrate & 15.6 & 14.8 & 0.78 & 0.19 \\
\hline Isovalerate & 1.81 & 1.89 & 0.061 & 0.31 \\
\hline Valerate & 3.17 & 3.34 & 0.101 & 0.05 \\
\hline Acetate:propionate & 2.58 & 2.53 & 0.131 & 0.53 \\
\hline Total protozoa, $\times 10^{4} / \mathrm{mL}$ & 70.4 & 80.3 & 8.8 & $0.41^{5}$ \\
\hline Entodinium spp. & 65.9 & 74.9 & 8.4 & 0.42 \\
\hline Isotricha spp. & 0.8 & 1.5 & 0.15 & 0.64 \\
\hline Dasytricha spp. & 1.0 & 1.5 & 0.27 & 0.29 \\
\hline Epidinium spp. & 0.3 & 0.9 & 0.67 & 0.36 \\
\hline Ophryoscolex spp. & 0.6 & 0.2 & 0.35 & 0.28 \\
\hline Diplodinium spp. & 1.7 & 1.3 & 0.45 & 0.24 \\
\hline \multicolumn{5}{|l|}{ PSD activities ${ }^{6}$} \\
\hline CMCase & 160.8 & 196.8 & 23.08 & 0.29 \\
\hline Xylanase & 232.3 & 200.6 & 25.20 & 0.12 \\
\hline Amylase & 101.4 & 131.2 & 12.62 & 0.10 \\
\hline Methane production, $\mathrm{g} / \mathrm{h}$ & 9.7 & 10.0 & 1.40 & $0.48^{7}$ \\
\hline \multicolumn{5}{|l|}{ Urinary $\mathrm{PD},{ }^{8} \mathrm{mmol} / \mathrm{d}$} \\
\hline Allantoin & 597 & 654 & 48.3 & 0.08 \\
\hline Uric acid & 88 & 87 & 5.7 & 0.90 \\
\hline Total PD & 685 & 741 & 49.9 & 0.10 \\
\hline $\mathrm{MN},{ }^{9} \mathrm{~g} / \mathrm{d}$ & 333 & 364 & 24.0 & 0.08 \\
\hline \multicolumn{5}{|l|}{ Blood plasma, mg/100 mL } \\
\hline Glucose & 55.4 & 58.0 & 0.96 & 0.14 \\
\hline Urea & 11.6 & 12.0 & 0.45 & 0.26 \\
\hline
\end{tabular}

${ }^{1}$ Treatment $\times$ time interaction, $P=0.58$.

${ }^{2}$ Treatment $\times$ time interaction, $P=0.80$.

${ }^{3}$ Total free amino acids.

${ }^{4}$ There was no treatment $\times$ time interaction for any of the VFA data $(P=0.18$ to 0.78$)$.

${ }^{5}$ Actual protozoal counts were $\log _{10}$ transformed for the statistical analysis.

${ }^{6}$ Expressed as nanomoles of reducing sugars as glucose released per milliliter of ruminal fluid per minute; CMCase $=$ carboxymethylcellulase.

${ }^{7}$ Treatment $\times$ time interaction, $P=0.19$.

${ }^{8}$ Excretion of urinary PD.

${ }^{9}$ Estimated microbial N outflow from the rumen (based on PD excretion; see Materials and Methods). 


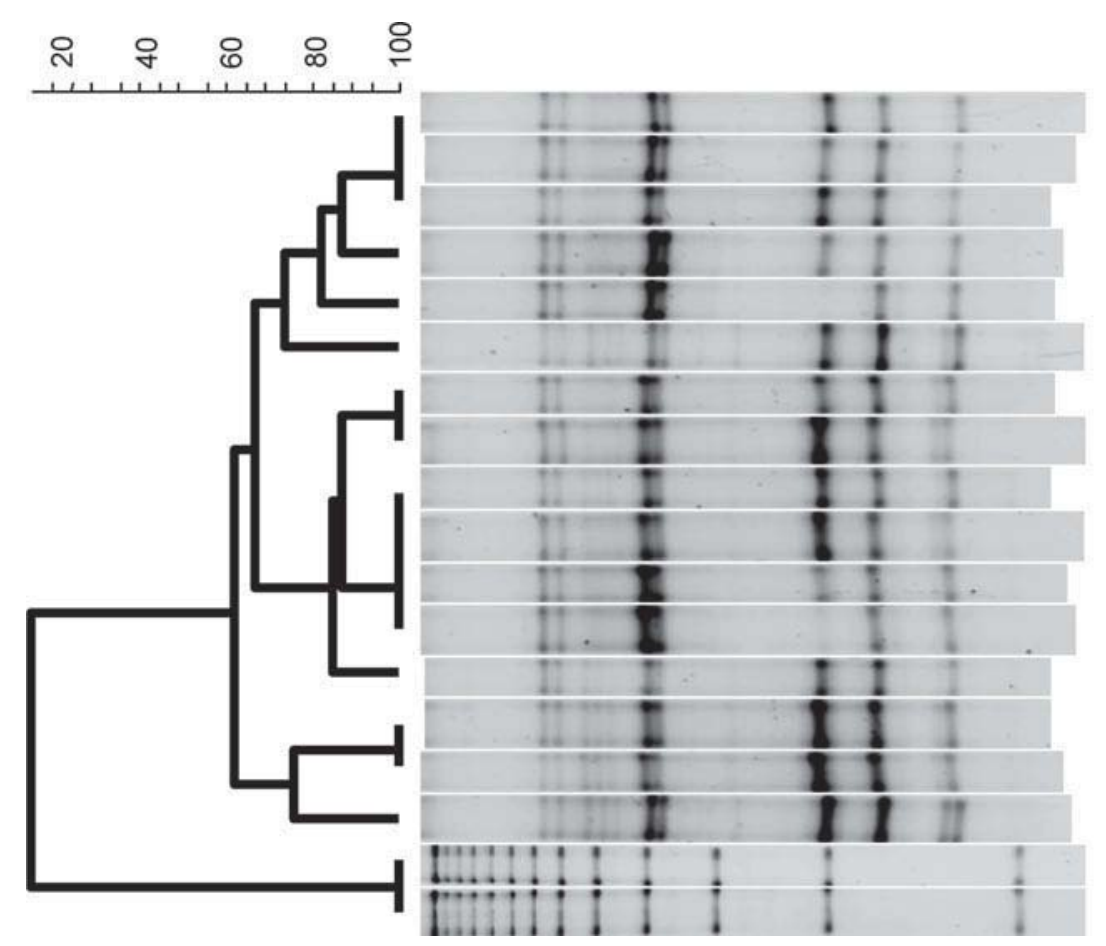

Cow 1151, XP
Cow 1306, Control
Cow 1393, XP
Cow 1337, Control
Cow 1379, XP
Cow 1302, Control
Cow 1306, XP
Cow 1403, Control
Cow 1151, Control
Cow 1393, Control
Cow 1337, XP
Cow 1379, Control
Cow 1403, XP
Cow 1302, XP
Cow 1331, XP
Cow 1331, Control
MARKER
MARKER

Figure 1. Denaturing gradient gel electrophoresis profiles of methanogens produced from community DNA samples from whole ruminal contents from cows fed control or yeast-supplemented (XP, Diamond V Mills, Cedar Rapids, IA) diets. The lanes are labeled with the cow number and treatment. The calculated similarity coefficients determined using Bionumerics software (Applied Maths Inc., Austin, TX) are shown on the top left-hand side.

XP (Table 2). Rate of methane production did not change $(P=0.85)$ within the $6 \mathrm{~h}$ of sampling following the a.m. feeding and XP supplementation (data not shown). There was no treatment by time interaction for this variable. The methanogen-specific DGGE analysis revealed similar banding patterns for both the control and the XP-supplemented diets (Figure 1). About 7 to 8 bands were amplified from all samples. However, the samples clustered mostly by experimental period because treatment did not have any specific effect on the DGGE banding patterns.

Excretion of urinary allantoin and consequently total PD (allantoin and uric acid in this experiment) in urine tended to be increased ( $P=0.08$ and 0.10 , respectively) by XP compared with the control (Table 2). As a result, the estimated duodenal MN flow also tended to be increased (by $9 \% ; P=0.08$ ) by XP compared with the control. The improved equation of Firkins et al. (2006) gave estimates for duodenal $\mathrm{MN}$ flow $0.71 \pm 0.005$ of the estimates derived using the equation of Chen and Gomes (1992): 471 versus $513 \mathrm{~g}$ of N/d (SEM = 32.4) for control and XP, respectively. Concentrations of blood plasma urea and glucose were not different between treatments.

Intake of DM (Table 3), OM, N, NDF, and starch were not affected by treatment $(P=68$ to 0.72 ; data not shown). Apparent total-tract digestibilities of
DM $(61.1$ and $62.0 \%, \mathrm{SEM}=0.83$; control and XP, respectively), OM (62.4 and $63.2 \%, \mathrm{SEM}=0.95), \mathrm{N}$ (57.3 and $58.3 \%, \mathrm{SEM}=1.24)$, NDF (39.7 and $41.1 \%$, SEM = 1.78), and starch (97.0 and 97.1\%, SEM = $0.20)$ were similar between XP and the control $(P=$ 0.46 to 0.67 ). Absolute or relative, as proportion of $\mathrm{N}$ intake, fecal and total (urinary and fecal) $\mathrm{N}$ losses were also not affected by treatment $(P=0.40$ to 0.85 ; data not shown). Urinary $\mathrm{N}$ loss was numerically lower for XP compared with the control (0.201 vs. $0.206 \mathrm{~kg} / \mathrm{d}$, respectively; $P=0.12$, SEM $=0.0105)$. As proportion of $\mathrm{N}$ intake, urinary $\mathrm{N}$ losses were similar $(P=0.34)$ between treatments.

Milk yield, 4\% FCM, and ECM yield were not affected by XP (Table 3). Milk fat and true protein concentrations and yields and milk $\mathrm{N}$ efficiency (milk true protein $\mathrm{N} \div \mathrm{N}$ intake) were also not affected by treatment. Similarly, concentrations of lactose and MUN in milk and BW of cows were not affected by treatment.

Overall, milk fatty acid composition was not altered by XP supplementation (Table 4). Proportions of milk fatty acids derived from de novo fatty acid synthesis and preformed fatty acid uptake were not affected by treatment. A significant but numerically small reduction $(P=0.03)$ in palmitate content and a reciprocal increase (10.8 vs. $11.4 \%$; $\mathrm{SEM}=0.43 ; P=0.008)$ in stearate content (data not shown) were observed with 
Table 3. Effect of yeast culture (XP, Diamond V Mills, Cedar Rapids, IA) on milk yield and composition in dairy cows (DMI, $\mathrm{n}=126$; milk yield, $\mathrm{n}=115$; all other variables, $\mathrm{n}=16$ )

\begin{tabular}{lcccc}
\hline Item & Control & XP & SEM & $P$-value \\
\hline DMI, kg/d & 27.4 & 27.6 & 2.11 & 0.69 \\
Milk yield, kg/d & 46.5 & 46.4 & 2.26 & 0.95 \\
Milk/DMI & 1.72 & 1.73 & 0.080 & 0.90 \\
Milk fat, \% & 3.48 & 3.27 & 0.130 & 0.13 \\
Yield, kg/d & 1.60 & 1.51 & 0.076 & 0.25 \\
$4 \%$ FCM, kg/d & 42.6 & 41.3 & 1.89 & 0.41 \\
Milk true protein, \% & 2.94 & 2.93 & 0.054 & 0.81 \\
Yield, kg/d & 1.37 & 1.36 & 0.083 & 0.94 \\
N yield, kg/d & 0.214 & 0.214 & 0.0130 & 0.94 \\
As \% of N intake & 30.7 & 30.5 & 0.99 & 0.89 \\
ECM yield, ${ }^{2} \mathrm{~kg} / \mathrm{d}$ & 45.8 & 44.6 & 2.17 & 0.48 \\
Milk lactose, \% & 4.77 & 4.77 & 0.099 & 0.94 \\
MUN, mg/100 mL & 10.0 & 10.2 & 0.48 & 0.73 \\
BW, kg & 641 & 637 & 32.9 & 0.38
\end{tabular}

${ }^{1}$ Milk true protein yield $\div 6.38$.

${ }^{2} \mathrm{ECM}$ yield $=$ milk yield, $\mathrm{kg} / \mathrm{d} \times[0.327+(7.2 \times$ milk true protein, $\% \div 100)+(12.95 \times$ milk fat, $\% \div$ $100)]$.

XP supplementation. Alterations in the concentration and composition of biohydrogenation intermediates present in milk fat were not observed in this experiment.

End-point $(253 \mathrm{~h})$ cumulative ammonia, methane, and carbon dioxide emissions from manure were not different $(P=0.39$ to 0.49$)$ between the control and XP: 1,202 versus $1,151 \mathrm{mg}, 94$ versus $85 \mathrm{mg}$, and 20 versus $21 \mathrm{~g}$, respectively. The predicted theoretical maximum of methane (126 vs. $115 \mathrm{mg}$ ) and the overall cumulative ammonia and methane emissions (Figures 2 and 3) were decreased $(P=0.01, P<0.001$, and $P$ $=0.002$, respectively) by XP compared with the control. The predicted theoretical maximum of ammonia emissions from manure was similar $(P=0.27)$ between treatments (2,629 and 2,464 $\mathrm{mg}$, respectively).

\section{DISCUSSION}

As noted by Beauchemin et al. (2006), comparison of animal responses to $\mathrm{YP}$ across studies is complicated by the type of product [live yeast (highly concentrated live yeast), yeast culture (yeast cells with varying viability and the fermentation medium on which they were grown; Fonty and Chaucheyras-Durand, 2006), or yeast product (a general term representing both live yeast and yeast culture)], variability among YP, and the effectiveness of strains within the same species $(S$. cerevisiae, for example) to influence ruminal fermentation. In many cases, the effect will depend on the composition of the diet fed. Overall, the YC tested in this experiment had subtle effects on ruminal fermentation, except that ammonia concentration tended to be lower compared with the control for most of the feeding cycle. No other significant effects of XP on ruminal fermentation were observed. The increased valerate concentration with XP is difficult to explain and is perhaps of little biological significance. Ruminal VFA responses to YP supplementation have been inconsistent (Martin and Nisbet, 1992; Newbold et al., 1996; Marden et al., 2008; Longuski et al., 2009).

In theory, the enhanced bacterial growth in the rumen observed in some studies with YP may be due in part to

Table 4. Effect of yeast culture (XP, Diamond V Mills, Cedar Rapids, IA) on milk fatty acid composition (g/100 $\mathrm{g}$ fatty acids) of dairy cows $(\mathrm{n}=16)$

\begin{tabular}{|c|c|c|c|c|}
\hline Variable & Control & $\mathrm{XP}$ & SEM & $P$-value \\
\hline \multicolumn{5}{|c|}{ Summation of fatty acids ${ }^{1}$} \\
\hline$<\mathrm{C} 16$ & 26.2 & 26.1 & 0.53 & 0.81 \\
\hline C16 & 25.6 & 25.2 & 0.84 & 0.03 \\
\hline$>\mathrm{C} 16$ & 47.0 & 47.4 & 0.53 & 0.38 \\
\hline \multicolumn{5}{|c|}{ Biohydrogenation intermediates $^{2}$} \\
\hline trans-C18:1 & 4.2 & 4.1 & 0.37 & 0.34 \\
\hline CLA, cis-9, trans -11 & 0.64 & 0.60 & 0.07 & 0.15 \\
\hline
\end{tabular}

${ }^{1}$ Summation of fatty acids according to origin. Fatty acids with fewer than 16 carbons are synthesized de novo, fatty acids with 16 carbons are partially synthesized de novo and partially taken up from circulation, and fatty acids with more than 16 carbons are preformed fatty acids and exclusively taken up from circulation.

${ }^{2}$ Fatty acids containing trans double bonds are produced during the biohydrogenation of 18-carbon polyunsaturated fatty acids. CLA = conjugated linoleic acid 


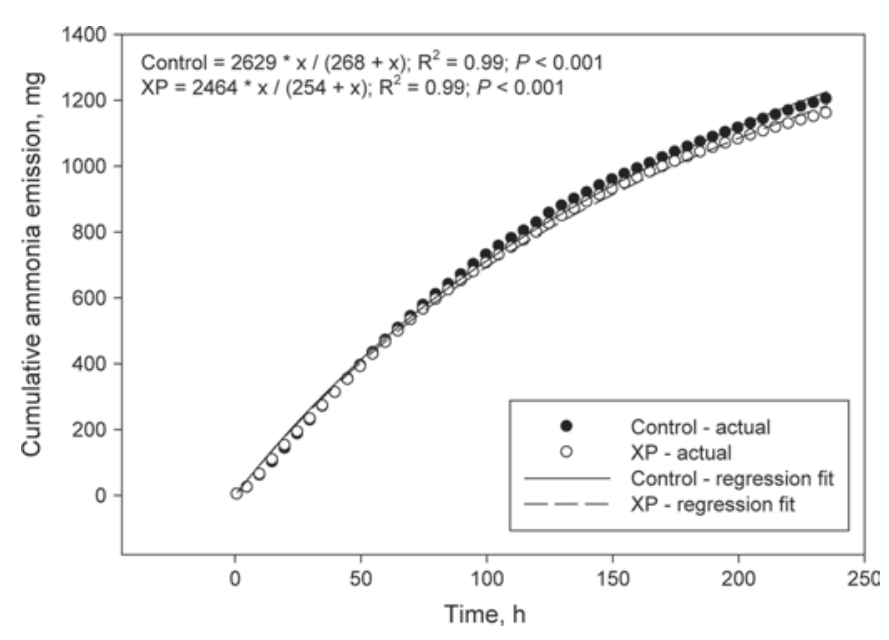

Figure 2. Effect of yeast culture (XP, Diamond V Mills, Cedar Rapids, IA) on cumulative ammonia emission from dairy manure (emission lines, $P<0.001$ ).

inhibition of protozoal growth and activities. Newbold et al. (1998), for example, used this mode of action to explain a $25 \%$ increase in total bacterial counts with $S$. cerevisiae $\mathrm{YC}$ in vitro. In most studies, however, similar to results from this experiment, protozoal counts were not affected by YP supplementation (Lila et al., 2004; Brossard et al., 2006; Kowalik et al., 2008; studies with live yeast).

Urinary $\mathrm{N}$ excretion or total $\mathrm{N}$ losses have rarely been reported in experiments with YP. Mwenya et al. (2004) observed no effect of YC (T. sericeum) on urinary or fecal absolute or relative (as proportion of $\mathrm{N}$ intake) $\mathrm{N}$ losses in sheep. In the current experiment, urinary $\mathrm{N}$ losses were also not affected by XP, although there was a slight $(2.5 \%)$ numerical decrease in urinary $\mathrm{N}$ excretion compared with the control. This reduction probably has no biological significance, but is in agreement with the observed trend for reduced ruminal ammonia concentration with XP. Urinary allantoin excretion and the estimated microbial protein outflow from the rumen also tended to be increased by XP. The improved equation of Firkins et al. (2006) for estimating duodenal MPB flow gave about 30\% lower MN flow estimates compared with the equations of Chen and Gomes (1992) and was closer to the average MN flow predicted by NRC (2001) for the basal diet used in this experiment $(360 \mathrm{~g}$ of $\mathrm{N} / \mathrm{d})$. As both approaches are based on urinary PD excretion (allantoin or allantoin and uric acid), the ranking between treatments was similar. The Firkins et al. (2006) prediction equation is derived from multiple studies with different animals and dietary conditions and should be more robust for prediction of duodenal MPB flow compared with the equations of Chen and Gomes (1992). A more recent analysis, using the Firkins et al. (2006) approach, proposed a similar MPB flow prediction equation (Tas and Susenbeth, 2007). The observed trend for increased MN flow with XP in this experiment is in accord with the general concept of improved environmental conditions in the rumen reported for various YP and diets (Erasmus et al., 1992). As with other rumen variables, however, the effect of YP on microbial protein synthesis has been inconsistent (Firkins et al., 1990; Carro et al., 1992, both YC).

Ruminal methane production rate was not affected by XP in this experiment. Mwenya et al. (2004) reported a $10 \%$ decrease in methane production in sheep fed a $70 \%$ forage $/ 30 \%$ concentrate diet supplemented with T. sericeum $\mathrm{YC}$, but production of methane per unit of DMI was similar to that of the control. A more recent Canadian study, however, found no effect of commercial YP on methane production in beef cattle (McGinn et al., 2004). Methanogen-specific DGGE did not reveal any treatment-specific banding patterns and this result was supported by the lack of differences in ruminal methane production and $\mathrm{pH}$, protozoal counts, and other ruminal fermentation characteristics. Interestingly, one of the experimental cows (cow 1379) lost a band (in both periods) that was prominent in samples from other cows, but the absence of the methanogen population represented by this band did not affect ruminal methane production. Karnati et al. (2009) also did not observe any differences in methane production from continuous culture fermenters despite changes in DGGE banding profiles. These authors discussed that methane production in the rumen is perhaps not affected as much by methanogen abundance or diversity

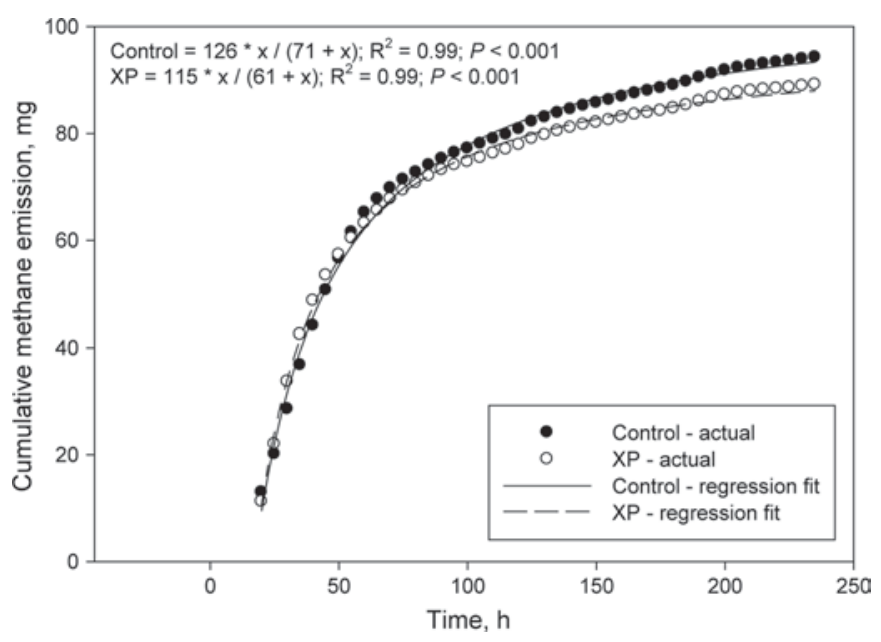

Figure 3. Effect of yeast culture (XP, Diamond V Mills, Cedar Rapids, IA) on cumulative methane emission from dairy manure (emission lines, $P=0.002$; regression fit from 20 to $235 \mathrm{~h}$ only; a lag in methane emission was observed from 0 to $20 \mathrm{~h}$, and these data points were excluded from the regression). 
of the ruminal methanogen populations, but is more affected by the accumulation of hydrogen in the rumen enhancing methane production.

The XP treatment resulted in a subtle but significant decrease in cumulative ammonia emission from manure. The effect, presumably resulting from effects on ruminal fermentation, can be explained by the slight numerical reduction in urinary $\mathrm{N}$ excretion with XP. The amount of urinary urea excreted with cattle manure is the single most important factor influencing ammonia emissions (Ndegwa et al., 2008). Usually, such effects are reported for diets differing in $\mathrm{CP}$ and RDP content (Hristov and Huhtanen, 2008), but in the present study the presumed improvement in ruminal $\mathrm{N}$ utilization is the most likely factor causing the reduction in manure ammonia emission. Similar to ammonia, cumulative methane emission from manure was also reduced (by about $10 \%$ vs. $4 \%$ reduction for ammonia) by XP. Methane emission from farm animal waste is dependent to a large extent on diet composition (Hashimoto et al., 1981) but also on various factors such as manure type, manure composition, and bedding (Massé et al., 2008). Methane formation in manure is a microbiological process, and factors that stimulate or inhibit methanogenic species would affect the amount of methane emitted. Available carbon, manure $\mathrm{pH}$ (VFA concentration), and physicochemical characteristics, temperature, and microbial population can all affect methane formation. In the current experiment, fecal N, NDF, and starch concentrations were similar between XP and the control $(P=0.44$ to 0.91$)$. No other fecal physical or chemical analyses were performed and thus, it is difficult to explain the difference in methane production between treatments.

Production variables were not affected by treatment in the current experiment. In general, production responses to YP supplementation have been variable. Two recent comprehensive meta-analyses, however, reported an overall positive effect of various YP on milk yield in dairy cows (Desnoyers et al., 2009; Robinson and Erasmus, 2009). In the Robinson and Erasmus (2009) review, the XP product tested in the current experiment increased milk yield by $3.6 \%$ on average (over the control). The basal diet used in the current study had a relatively low concentration of $\mathrm{CP}$, but the estimated (NRC, 2001) metabolizable protein supply was adequate $(+46 \mathrm{~g} / \mathrm{d})$ for the needs of the cows at the DMI and production level observed during the study. If this estimation is accurate, the additional microbial protein supply resulting from XP (as estimated based on urinary PD excretion) would not trigger a production response.

This is only the second report characterizing the response of milk fatty acid composition to YP supplemen- tation in lactating dairy cows. In a previous report with the XP product, Longuski et al. (2009) also observed no changes in overall milk fatty acid composition. Although XP supplementation caused small changes in palmitate and stearate concentrations in the current experiment, these changes were minor. In the absence of other changes in fatty acid composition, such as changes in de novo synthesized fatty acids or preformed fatty acids, these changes appear to be unrelated to a specific treatment effect of the XP product. Furthermore, a role of YP in modifying rumen microbial activity has been hypothesized (Beauchemin et al., 2006), but changes in the content or composition of fatty acid biohydrogenation intermediates were not observed in this experiment. Changes in the composition of trans fatty acids can indicate changes in the populations of biohydrogenating bacteria present in the rumen, typically manifested by increases in the amount of trans-10 18:1 present in milk fat (Bauman and Griinari, 2003).

\section{CONCLUSIONS}

The S. cerevisiae fermentation product (Original XP, Diamond V Mills Inc.) tested in this experiment tended to reduce ruminal ammonia concentration and increase microbial protein synthesis in the rumen of dairy cows. The XP product had no other effects on ruminal fermentation or on nutrient digestibility, $\mathrm{N}$ losses, milk yield, and milk composition. Manure from cows fed the XP-supplemented diet had decreased ammonia and methane emitting potential.

\section{ACKNOWLEDGMENTS}

This study was supported by funds from Diamond V Mills Inc. (Cedar Rapids, IA). The authors thank K. Johnson (Department of Animal Science, Washington State University, Pullman) for providing the $\mathrm{SF}_{6}$ permeation tubes, P. Topper (Department of Agricultural and Biological Engineering, Pennsylvania State University, University Park) for analyzing gaseous emission potential of manure, W. Price (Statistical Programs, College of Agricultural and Life Sciences, University of Idaho, Moscow) for assistance with statistical evaluation of the results, and the staff of the Department of Dairy and Animal Science Dairy Center (University of Idaho) for their conscientious care of the experimental cows.

\section{REFERENCES}

AOAC. 1980. Official Methods of Analysis. 13th ed., AOAC, Arlington, VA.

AOAC. 2000. Official Methods of Analysis. 17th ed., AOAC, Arlington, VA. 
Bates, D. M., and D. G. Watts. 1988. Nonlinear Regression Analysis and Its Applications. John Wiley \& Sons, New York, NY.

Bauman, D. E., and J. M. Griinari. 2003. Nutritional regulation of milk fat synthesis. Annu. Rev. Nutr. 23:203-227.

Beauchemin, K. A., C. R. Krehbiel, and C. J. Newbold. 2006. Enzymes, bacterial direct-fed microbials and yeast: Principles for use in ruminant nutrition. Pages 251-284 in Biology of Nutrition in Growing Animals. R. Mosenthin, J. Zentek, and T. Żebrowska, ed. Elsevier, Amsterdam, the Netherlands.

Brossard, L., F. Chaucheyras-Durand, B. Michalet-Doreau, and C. Martin. 2006. Dose effect of live yeast on rumen microbial communities and fermentations during butyric latent acidosis in sheep: New type of interaction. Anim. Sci. 82:829-836.

Bryant, M. P. 1973. Nutritional requirements of the predominant rumen cellulolytic bacteria. Fed. Proc. 32:1809-1813.

Bussink, D. W., and O. Oenema. 1998. Ammonia volatilization from dairy farming systems in temperate areas: A review. Nutr. Cycl. Agroecosyst. 51:19-33.

Callaway, E. S., and S. A. Martin. 1997. Effects of a Saccharomyces cerevisiae culture on ruminal bacteria that utilize lactate and digest cellulose. J. Dairy Sci. 80:2035-2044.

Carro, M. D., P. Lebzien, and K. Rohr. 1992. Effect of yeast culture on rumen fermentation, digestibility and duodenal flow in dairy cows fed a silage based diet. Livest. Prod. Sci. 32:219-229.

Chaney, A. L., and E. P. Marbach. 1962. Modified reagents for determination of urea and ammonia. Clin. Chem. 8:130-132.

Chen, X. B. 1989. Excretion of purine derivatives by sheep and cattle and its use for estimation of absorbed microbial protein. $\mathrm{PhD}$ Thesis. University of Aberdeen, United Kingdom.

Chen, X. B., and M. J. Gomes. 1992. Estimation of microbial protein supply to sheep and cattle based on urinary excretion of purine derivatives: An overview of technical details. Int. Feed Res. Unit, Occasional Publ. Rowett Research Institute, Aberdeen, United Kingdom.

Christie, W. W. 1982. A simple procedure for rapid transmethylation of glycerolipids and cholesteryl esters. J. Lipid Res. 23:10721075.

Dehority, B. A. 1993. Laboratory Manual for Classification and Morphology of Rumen Ciliate Protozoa. CRC Press Inc., Boca Raton, FL.

Desnoyers, M., S. Giger-Reverdin, G. Bertin, C. Duvaux-Ponter, and D. Sauvant. 2009. Meta-analysis of the influence of Saccharomyces cerevisiae supplementation on ruminal parameters and milk production of ruminants. J. Dairy Sci. 92:1620-1632.

Enjalbert, F., J. E. Garrett, R. Moncoulon, C. Bayourthe, and P. Chicoteau. 1999. Effects of yeast culture (Saccharomyces cerevisiae) on ruminal digestion in non-lactating dairy cows. Anim. Feed Sci. Technol. 76:195-206.

Erasmus, L. J., P. M. Botha, and A. Kistner. 1992. Effect of yeast culture supplement on production, rumen fermentation, and duodenal nitrogen flow in dairy cows. J. Dairy Sci. 75:30563065 .

Firkins, J. L., A. N. Hristov, M. B. Hall, and G. A. Varga. 2006. Integration of ruminal metabolism in dairy cattle. J. Dairy Sci. 89(E. Suppl.):E31-E51

Firkins, J. L., W. P. Weiss, M. L. Eastridge, and B. L. Hull. 1990. Effects of feeding fungal culture extract and animal-vegetable fat on degradation of hemicelluloses and on ruminal bacterial growth in heifers. J. Dairy Sci. 73:1812-1822.

Foley, A. E., A. N. Hristov, A. Melgar, J. K. Ropp, R. P. Etter, S. Zaman, C. W. Hunt, K. Huber, and W. J. Price. 2006. Effect of barley and its amylopectin content on ruminal fermentation and nitrogen utilization in lactating dairy cows. J. Dairy Sci. 89:4321-4335.

Fonty, G., and F. Chaucheyras-Durand. 2006. Effects and modes of action of live yeasts in the rumen. Biologia (Bratisl.) 61:741750 .

Hara, A., and N. S. Radin. 1978. Lipid extraction of tissues with a low toxicity solvent. Anal. Biochem. 90:420-426.
Harrison, G. A., R. W. Hemken, K. A. Dawson, R. J. Harmon, and B. K. Barker. 1988. Influence of addition of yeast culture supplement to diets of lactating cows on ruminal fermentation and microbial population. J. Dairy Sci. 71:2967-2975.

Hashimoto, A. G., V. H. Varel, and Y. R. Chen. 1981. Ultimate methane yield from beef cattle manure: Effect of temperature, ration constituents, antibiotics, and manure age. Agric. Wastes $3: 241-256$.

Hristov, A. N., and P. Huhtanen. 2008. Nitrogen efficiency in Holstein cows and dietary means to mitigate nitrogen losses from dairy operations. Pages 125-136 in Proceedings, Cornell Nutrition Conference, Syracuse, NY. Cornell University, Ithaca, NY.

Hristov, A. N., T. A. McAllister, and K.-J. Cheng. 1998. Effect of dietary or abomasal supplementation of exogenous polysaccharidedegrading enzymes on rumen fermentation and nutrient digestibility. J. Anim. Sci. 76:3146-3156.

Hristov, A. N., M. Vander Pol, M. Agle, S. Zaman, C. Schneider, P. Ndegwa, V. K. Vaddella, K. Johnson, K. J. Shingfield, and S. K. R. Karnati. 2009. Effect of lauric acid and coconut oil on ruminal fermentation, digestion, ammonia losses from manure, and milk fatty acid composition in lactating cows. J. Dairy Sci. 92:55615582 .

Johnson, K. A., M. T. Huyler, H. H. Westberg, B. K. Lamb, and P. Zimmerman. 1994. Measurement of methane emissions from ruminant livestock using a $\mathrm{SF}_{6}$ tracer technique. Environ. Sci. Technol. 28:359-362.

Karnati, S. K. R., Z. Yu, and J. L. Firkins. 2009. Investigating unsaturated fat, monensin, or bromoethanesulfonate in continuous cultures retaining ruminal protozoa. II. Interaction of treatment and presence of protozoa on prokaryotic communities. J. Dairy Sci. 92:3861-3873.

Kelsey, J. A., B. A. Corl, R. J. Collier, and D. E. Bauman. 2003. The effect of breed, parity, and stage of lactation on conjugated linoleic acid (CLA) in milk fat from dairy cows. J. Dairy Sci. $86: 2588-2597$.

Kowalik, B., T. Michalowski, J. J. Pajat, M. Taciak, and J. Rawa. 2008. The effect of supplementing cows with live yeast, Saccharomyces cerevisiae on ciliate fauna and ruminal fermentation. J. Anim. Feed Sci. 17:157-165.

Lila, Z. A., N. Mohammed, T. Yasui, Y. Kurokawa, S. Kanda, and H. Itabashi. 2004. Effects of a twin strain of Saccharomyces cerevisiae live cells on mixed ruminal microorganism fermentation in vitro. J. Anim. Sci. 82:1847-1854.

Longuski, R. A., Y. Ying, and M. S. Allen. 2009. Yeast culture supplementation prevented milk fat depression by a short-term dietary challenge with fermentable starch. J. Dairy Sci. 92:160167.

Marden, J. P., C. Julien, V. Monteils, E. Auclair, R. Moncoulon, and C. Bayourthe. 2008. How does live yeast differ from sodium bicarbonate to stabilize ruminal $\mathrm{pH}$ in high-yielding dairy cows? J. Dairy Sci. 91:3528-3535.

Martin, S. A., and D. J. Nisbet. 1992. Effect of direct-fed microbials on rumen microbial fermentation. J. Dairy Sci. 75:1736-1744.

Massé, D. I., L. Masse, S. Claveau, C. Benchaar, and O. Thomas. 2008. Methane emissions from manure storages. Trans. ASABE $51: 1775-1781$.

McCleary, B. V., V. Solah, and T. S. Gibson. 1994. Quantitative measurement of total starch in cereal flours and products. J. Cereal Sci. 20:51-58.

McGinn, S. M., K. A. Beauchemin, T. Coates, and D. Colombatto. 2004. Methane emissions from beef cattle: Effect of monensin, sunflower oil, enzymes, yeast, and fumaric acid. J. Anim. Sci. $82: 3346-3356$

Mwenya, B., B. Santoso, C. Sar, Y. Gamo, T. Kobayashi, I. Arai, and J. Takahashi. 2004. Effects of including $31-4$ galacto-oligosaccharides, lactic acid bacteria or yeast culture on methanogenesis as well as energy and nitrogen metabolism in sheep. Anim. Feed Sci. Technol. 115:313-326. 
Ndegwa, P. M., A. N. Hristov, J. Arogo, and R. E. Sheffield. 2008. A review of ammonia emissions mitigation techniques for concentrated animal feeding operations. Biosystems Eng. 100:453-469.

Newbold, C. J., F. M. McIntosh, and R. J. Wallace. 1998. Changes in the microbial population of a rumen-simulating fermenter in response to yeast culture. Can. J. Anim. Sci. 78:241-244.

Newbold, C. J., R. J. Wallace, X. B. Chen, and F. M. McIntosh. 1995. Different strains of Saccharomyces cerevisiae differ in their effects on ruminal bacterial numbers in vitro and in sheep. J. Anim. Sci. 73:1811-1818.

Newbold, C. J., R. J. Wallace, and F. M. McIntosh. 1996. Mode of action of the yeast Saccharomyces cerevisiae as a feed additive for ruminants. Br. J. Nutr. 76:249-261.

NRC. 2001. Nutrient Requirements of Dairy Cattle. 7th rev. ed. National Academy Press, Washington, DC.

Robinson, P. H., and L. J. Erasmus. 2009. Effects of analyzable diet components on responses of lactating dairy cows to Saccharomyces cerevisiae based yeast products: A systematic review of the literature. Anim. Feed Sci. Technol. 149:185-198.

Snell, F. D., and C. T. Snell. 1954. Amino acids. Pages 104-169 in Colorimetric Methods of Analysis. Vol. 4. F. D. Snell and C. T. Snell, ed. D. Van Nostrand Company Inc. New York, NY.
Tas, B. M., and A. Susenbeth. 2007. Urinary purine derivates excretion as an indicator of in vivo microbial $\mathrm{N}$ flow in cattle: A review. Livest. Sci. 111:181-192.

Valadares, R. F. D., G. A. Broderick, S. C. Valadares Filho, and M. K. Clayton. 1999. Effect of replacing alfalfa silage with high moisture corn on ruminal protein synthesis estimated from excretion of total purine derivatives. J. Dairy Sci. 82:2686-2696.

Van Keulen, J., and B. A. Young. 1977. Evaluation of acid-insoluble ash as a natural marker in ruminant digestibility studies. J. Anim. Sci. $44: 282-287$.

Van Soest, P. J., J. B. Robertson, and B. A. Lewis. 1991. Methods for dietary fiber, neutral detergent fiber, and nonstarch polysaccharides in relation to animal nutrition. J. Dairy Sci. 74:3583-3597.

Wheeler, E. F., P. A. Topper, N. E. Brown, and G. A. Varga. 2007. Multiple-chamber steady-state gas emission detection from dairy manure slurry. Proceedings of the International Symposium on Air Quality and Waste Management for Agriculture, Broomfield, CO ASABE Publication Number 701P0907cd.

Yang, C.-M. Jr., and G. A. Varga. 1989. Effect of three concentrate feeding frequencies on rumen protozoa, rumen digesta kinetics, and milk yield in dairy cows. J. Dairy Sci. 72:950-957. 